\title{
PERBEDAAN MOTIVASI BELAJAR PESERTA DIDIK BIDANG STUDI EKONOMI MENGGUNAKAN MODEL EVERYONE IS A TEACHER DAN STUDENT FACILITATOR AND EXPLAINING MATERI POKOK PENGANGGURAN DI KELAS X SMA NEGERI 1 PADANG BOLAK JULU
}

\author{
Ali Nurdin Siregar1) Mukhlis Yakub ${ }^{2)}$ \\ 1,2)Prodi Pendidikan Ekonomi FKIP Universitas Muhammadiyah Tapanuli Selatan
}

\begin{abstract}
Abstrak
Penelitian ini bertujuan untuk mengetahui apakah ada perbedaan antara model pembelajaran Everyone Is A Teacher dengan model Pembelajaran Student Facilitator And Explaining terhadap motivasi belajar peserta didik pada bidang studi ekonomi dengan materi pokok pengangguran di kelas X SMA Negeri 1 Padang Bolak Julu Tahun Pelajaran 2018-2019. Jenis penelitian yang digunakan adalah penelitian kuantitatif komparatif, yaitu penelitian yang bersifat membandingkan variable yang pertama dengan variable yang kedua terhadap objek yang sama. Penelitian ini menggunakan pendekatan penelitian kepustakaan dan pendekatan penelitian lapangan dengan menggunakan angket. Populasi dalam penelitian ini adalah seluruh kelas X SMA Negeri 1 Padang Bolak Julu. Sampel penelitian berjumlah 65 orang peserta didik yang terdiri dari dua kelas yaitu kelas X IPS 1 dan X IPS 2. Penelitian ini menggunakan rumus Polled Varian hasil $r_{\text {hitung }}=1$, dibandingkan dengan $r_{\text {tabel }}$ dimana $r_{\text {hitung }}$ lebih besar dari $r_{\text {tabel }}$ yaitu $1>0,244$. Dengan demikian, ada perbedaan model pembelajaran Everyone Is A Teacher dengan model pembelajaran Student Facilitator And Explaining terhadap motivasi belajar peserta didik bidang studi Ekonomi materi pokok Pengangguran di kelas X SMA Negeri 1 Padang Bolak Julu.
\end{abstract}

Kata Kunci: Motivasi Belajar, Model Pembelajaran, Everyone Is A Teacher, Student Facilitator And Explaining

*Correspondence Address : ali.nurdin@um-tapsel.ac.id DOI : 10.31604/jips.v6i2.2019.175-179

(C) 2019 Fakultas Keguruan \& Ilmu Pendidikan UM-Tapanuli Selatan 


\section{PENDAHULUAN}

$\begin{array}{lrr}\text { Pendidikan } & \text { merupakan } & \text { suatu } \\ \text { proses yang } & \text { disadari } & \text { untuk } \\ \text { mengembangkan } & \text { potensi } & \text { individu } \\ \text { sehingga memiliki } & \text { kecerdasan } & \text { berfikir, } \\ \text { emosional, } & \text { berwatak dan } \\ \text { berketerampilan } & \text { untuk siap } & \text { hidup di } \\ \text { tengah-tengah } & \text { masyarakat. }\end{array}$

Keberhasilan proses-pembelajaran tidak terlepas dari kemampuan guru mengembangkan model-model pembelajaran yang berorientasi pada peningkatan intensitas keterlibatan peserta didik secara efektif di dalam proses pembelajaran. Pengembangan model pembelajaran yang tepat pada dasarnya bertujuan untuk menciptakan kondisi pembelajaran yang memungkinkan peserta didik termotivasi untuk belajar secara aktif dan menyenangkan sehingga peserta didik dapat meraih hasil belajar dan prestasi yang optimal.

Berdasarkan observasi yang telah dilakukan oleh peneliti di SMA Negeri 1 Padang Bolak Julumenunjukkan bahwa proses pembelajaran khususnya Ekonomi masih mempergunakan model yang konvensional yaitu model ceramah monoton yang masih berfokus pada guru, sehingga peserta didik kurang temotivasi untuk aktif berperan dalam proses pembelajaran. Peserta didik yang kurang memiliki motivasi dalam belajar, maka hasil belajarnya tidak akan mencapai sasaran dan tidak terarah dalam pelaksanaannya, apabila seseorang belajar tanpa adanya dorongan yang menggerakkan atau mengarahkan maka situasi belajar tidak menggairahkan bahkan akan lebih cepat mengalami kelelahan atau kebosanan. Hasil angket yang telah disebarkan oleh peneliti juga semakin memperkuat bahwa motivasi belajar peserta didik masih sangat rendah.

Di era ini, ada banyak sekali model ataupun metode pembelajaran yang aktif dan kreatif yang bisa digunakan dalam proses pembelajaran agar proses pembelajaran lebih menarik dan efektif untuk meningkatkan motivasi belajar peserta didik, diantaranya adalah : Everyone Is A Teacher dan Student Facilitator and Explaining.

Model pembelajaran everyone is a teacher merupakan sebuah model pembelajaran yang mengajak peserta didik untuk aktif dan berupaya untuk menjadikan semua peserta didik sebagai narasumber. Seluruh peserta didik diberikan kesempatan untuk memberikan gagasan atau pandangan atau idenya untuk dikemukakan di depan peserta didik yang lain layaknya 
seperti seorang guru yang sedang memberikan penjelasan materi.

Ada beberapa langkah-langkah yang harus dilakukan oleh guru ketika menggunakan model pembelajaran everyone is a teacher, yaitu : (a)Guru memberikan bahan bacaan dan meminta peserta didik untuk membaca materi tersebut. (b) membagikan secarik kertas kepada seluruh peserta didik. (c) meminta peserta didik untuk membuat pertanyaan di kertas tersebut. meminta peserta didik mengumpulkan pertanyaan yang ditulis, ( e) kocoklah kertas pertanyaan tersebut, lalu bagikan kembali kepada seluruh peserta didik. (f) meminta peserta didik membaca dalam hati sambil memikirkan jawaban dari pertanyaan tersebut, (g) memanggil secara bergantian setiap peserta didik untuk membaca pertanyaan dan menerangkan kepada peserta didik yang lain, (h) meminta peserta didik lain untuk memberikan tanggapan, (i) Guru pada tahap akhir memberikan kesimpulan dari apa yang mereka pelajari.

Sedangkan model pembelajaran student facilitator and explaining merupakan model pembelajaran dimana peserta didik belajar mempersentasikan ide atau pendapatnya pada rekan peserta didik lainnya. Model pembelajaran ini efektif untuk melatih peserta didik berbicara untuk menyampaikan idea tau gagasan dan pendapatnya sendiri.Langkah-langkah yang harus dilakukan oleh guru ketika menggunakan model pembelajaran student facilitator and explaining yaitu: (a) menyampaikan kompetensi yang ingin dicapai, (b) mendemonstrasikan atau menyajikan materi, memberikan kesempatan peserta didik untuk menjelaskan kepada peserta didik lainnya misalnya melalui bagan atau peta konsep. (d) guru menyimpulkan ide atau pendapat dari peserta didik. (e)guru menerangkan semua materi yang disajikan saat itu dan terakhir , (f) Penutup.

\section{METODE PENELITIAN}

Metode pengambilan sampel dalam penelitian ini merupakan cluster sampling (sampling kelompok) yaitu dengan mengelompokkan populasi. Dimana setiap kelas merupakan suatu kelompok, sehingga kelas yang menjadi sampel adalah dengan dua kelas sebanyak 67 orang peserta didik di kelas X IPS 1 dan X IPS 2 SMA Negeri 1 Padang Bolak Julu Tahun Pelajaran 2018-2019.

Peneliti menggunakan angket untuk memperoleh data yang dibutuhkan dalam penelitian ini.dengan menggunakan instrumen berbentuk 
skala (scale), dengan gradasi frekuensi dibagi atas 3 (tiga) pilihan, yaitu selalu, kadang-kadang, tidak pernah. Dengan masing-masing skor sebagai berikut :

a. Untuk jawaban A diberi nilai 3 (ya)

b. Untuk jawaban B diberi nilai 2 (Kadang-kadang)

c. Untuk jawaban C diberi nilai 1 (tidak)

Data-data yang sudah terkumpul kemudian dianalisa lebih lanjut dengan menggunakan rumus Polled Varian.

\section{HASIL DAN PEMBAHASAN}

Berdasarkan hasil penelitian yang dilakukan, menunjukkan bahwa ada perbedaan saat menggunakan Model Everyone Is A Teacher dan Model Student Facilitator And Explaining terhadap motivasi belajar peserta didik bidang studi ekonomi materi pokok pengangguran di kelas X SMA Negeri 1 Padang Bolak Julu Tahun Pelajaran 2018 $-2019$.

Data yang diperoleh dari angket pada variabel everyone is a teacher menunjukkan persentase yang signifikan antara peserta didik yang menjawab "ya" sebanyak 90,05 \%, "kadang-kadang" sebanyak 8,62\% dan "tidak" dengan persentase sebanyak 1,33 \%. Hasil perolehan skor angket bidang studi ekonomi dengan model everyone is a teacher yang disampaikan oleh guru, menurut jawaban responden berjalan dengan sangat baik Kemudian,berdasarkan hasil angket untuk model pembelajaran student facilitator and explaining yaitu peserta didik yang menjawab "ya" sebanyak 86,77 \% “kadang-kadang” sebanyak 10,56\% dan "tidak" dengan persentase sebanyak 2,67\%. Selanjutnya , hasil untuk besarnya persentase angket motivasi belajar peserta didik menunjukkan hasil yaitu: ada 84,41\% peserta didik yang menjawab "ya", "kadang-kadang" sebanyak 10,78 \%dan "tidak" dengan persentase sebanyak $4,72 \%$.

Dari perhitungan dengan menggunakan t-test polled varians maka diperoleh $t_{\text {hitung nya senilai } 0,630 \text { dengan }}$ melihat daftar $t_{\text {tabel }}$ dengan jumlah sampel 65 kemudian digunakan derajat kebebasan $(\mathrm{dk})=\mathrm{n}_{1}+\mathrm{n}_{2}-2$ dan taraf kesalahan 5\% $(0,244)$. Sesuai dengan ketentuan jika $t_{\text {hitung }}>t_{\text {tabel }}(0,630>$ $0,244)$ maka hipotesis alternatif $(\mathrm{Ha})$ dapat diterima kebenarannya.

Setelah dilakukan pengujian hipotesis dengan rumus t-test polled varians diperoleh hasil $t_{\text {hitung }}=0,630$ sedangkan nilai $t_{\text {tabel }}=0,244$, ini menunjukkan $t_{\text {hitung }}>t_{\text {tabel }}$ artinya ada perbandingan model everyone is a 
teacher dengan model student facilitator and explaining terhadap motivasi belajar peserta didik bidang studi ekonomi materi pokok pengangguran di kelas X SMA Negeri 1 Padang Bolak Julu Tahun Pelajaran 2018 - 2019.

\section{SIMPULAN}

Berdasarkan hasil analisis yang telah peneliti lakukan, dapat disimpulkan bahwa:

1. Ada perbandingan model everyone is a teacher dengan model student facilitator and explaining terhadap motivasi belajar peserta didik bidang studi ekonomi materi pokok pengangguran di kelas X SMA Negeri 1 Padang Bolak Julu Tahun Pelajaran 2018 - 2019. Hal ini dapat dibuktikan dari nilai $t_{\text {hitung }}=0,630$ dengan melihat daftar tabel jumlah sampel nya 65 dan derajat kebebasan $(\mathrm{dk})=\mathrm{n}_{1}+\mathrm{n}_{2}-2$ untuk taraf kesalahan $5 \% \quad(0,244)$ sehingga dapat diketahui $t_{\text {hitung }}>t_{\text {tabel }}$ $(0,630>0,244) \quad$ makahipotesis alternatif (Ha) dapat diterima.

2. Perbandingan prestasi belajar peserta didik melalui model everyone is a teacher dengan model student facilitator and explaining terhadap motivasi belajar peserta didik bidang studi ekonomi materi pokok pengangguran di kelas X SMA Negeri 1 Padang Bolak Julu Tahun
Pelajaran 2018 - 2019 diperoleh $t_{\text {hitung }}=0,630$ dan $t_{\text {tabel }}=0,244$, dengan ketentuan jika $t_{\text {hitung }}>t_{\text {tabel }}$ maka Ha diterima dan Ho ditolak. Jadi kesimpulan dari penelitian ini yaitu ada perbandingan model everyone is a teacher dengan model student facilitator and explaining terhadap motivasi belajar peserta didik bidang studi ekonomi materi pokok pengangguran di kelas X SMA Negeri 1 Padang Bolak Julu Tahun Pelajaran 2018 - 2019 karena Ho ditolak dan Ha diterima

\section{DAFTAR PUSTAKA}

Winarno Surakhmad, (2005). Manajemen Pembelajaran, Jakarta: Kencana,

Jujun S.Surya Sumantri, (2006).Prosedur Penelitian, Jakarta: Tarsito,

Simarmata, (2010).Model Strategi Pembelajaran Konstektual, Bandung: Yrama Widia,

Dick \& Carelly, (2012)Model-Model Pembelajaran, Jakarta: Rajawali Pers,

Trianto, (2007)Model Pembelajaran Terpadu Dalam Teori dan Praktek, Jakarta: Prestasi Pustaka,

Abdussalam dan M.Siddik, (2014) 58 Model Pembelajaran Inovatif, Medan: Media Persada,

Hamzah B Uno, (2009). Model Pembelajaran: Menciptakan Proses Belajar MengajarYang Kreatif dan Efektif, Jakarta: Bumi Aksara, 